Global COE Hi-Stat Discussion Paper Series 021

$$
\begin{aligned}
& \text { Research Unit for Statistical } \\
& \text { and Empirical Analysis in Social Sciences (Hi-Stat) }
\end{aligned}
$$

What Lies behind Rising Earnings Inequality in Urban China? Regression-based Decompositions

Deng Quheng

Li Shi

January 2009 


\title{
What Lies behind Rising Earnings Inequality in Urban China? Regression-based Decompositions ${ }^{*}$
}

\author{
DENG Quheng \\ Chinese Academy of Social Sciences \\ and \\ LI Shi \\ Beijing Normal University
}

\begin{abstract}
Coupled with advances in enterprise reform and changes in the wage structure, earnings inequality in urban China has been increasing, and this has contributed significantly to rising income inequality. Using urban household survey data from the 1988, 1995 and 2002 waves of the China Household Income Project, in this paper, we decompose earnings inequality in urban China by using the regression-based decomposition methods developed by Fields (1998), Morduch and Sicular (2002) and Shorrocks (1999). The decomposition results indicate that the effects of gender and membership of the Communist Party of China on earnings inequality have changed little. While work experience had a reduced effect on earnings inequality, the effects of education and occupation have increased. The contributions of ownership status and industry to earnings inequality have increased. Regional effects have been the largest recent contributor to earnings inequality.
\end{abstract}

Key words: earnings inequality, regression-based decompositions, urban China

JEL Classifications: D31, J31, O53

\footnotetext{
* We are grateful for financial support for the preparation of this paper from the Global COE Program "Research Unit for Statistical and Empirical Analysis in Social Sciences” and the Fukino Project, Hitotsubashi University.
} 


\section{Introduction}

Rising earnings inequality in urban China, as one of many sources of widening income inequality, has drawn increasing attention. With the privatization of state-owned enterprises (SOEs), the development of private firms and the self-employment sector and the reform of wage systems, urban earnings inequality has been increasing since the mid-1990s, and this has led to rising income inequality within urban China (Gustafsson and Li, 2001; Khan and Riskin, 2005; Knight and Song, 2008). Our estimation results indicate that the Gini coefficient of earnings in urban China rose from 0.235 in 1988 to 0.302 in 1995, and then to 0.342 in 2002. Rising earnings inequality is partly caused by the introduction of market forces to wage determination, which provides stronger incentives to workers and greatly enhances efficiency. It also results from economic restructuring and labor market segmentation. In this paper, we aim to determine the driving forces behind rising earnings inequality in urban China and to quantify the relative effects of these forces.

In a planned economy, the main determinant of wage levels is seniority, which almost completely explains wage inequality (Knight and Song, 1994). By contrast, under the current wage scheme, the driving forces of wage differentials have diversified and are constantly changing. As indicated by previous studies, education, rather than work experience, has become the most important determinant of urban wages in China (Knight and Song, 2008). Moreover, institutional segmentation in the labor market, such as that based on industry, region, and ownership, has increased in the process of marketization and plays an important role in wage determination (Démurger et al., 2006). To evaluate the relative importance of each factor in wage determination, the conventional approach is to estimate earnings functions, from which one can gauge the average and marginal effects of different factors on wage levels. However, using this approach does not fully account for wage inequality among urban workers. Thus, researchers have used decomposition of the Gini coefficient by income sources or decomposition of the Theil indices by population groups. ${ }^{1}$ Useful as they are, these two decomposition approaches have limitations, which have been overcome by recently developed regression-based decomposition approaches. In this paper, based on estimated earnings functions, the approaches developed by Fields (1998), Morduch and Sicular (2002)

\footnotetext{
${ }^{1}$ For an example of the use of these two decomposition methods, see Gustafsson and Li (2001), who examine the change in earnings inequality in urban China from 1988 to 1995.
} 
and Shorrocks (1999) are employed to disentangle the effects of causal factors on earnings inequality in urban China.

This paper is structured as follows. In Section 2, we describe the institutional background behind the changes in urban earnings inequality and present a brief literature review. In Section 3, we discuss regression-based decomposition approaches. In Section 4, we describe the data used, and we present descriptive statistics and decompositions of earnings inequality by source. In Section 5, we estimate linear and logarithmic earnings functions. In Section 6, we present decompositions of several inequality indices of earnings based on our regression results. In Section 7, we present conclusions and discuss policy implications.

\section{Institutional Background and Related Literature}

Rising earnings inequality is linked to enterprise reforms, changes in wage determination and the market allocation of labor. In the early period of reform in the late 1970s, the overwhelming majority of enterprises were publicly owned. Wage levels in SOEs and collective enterprises were set by the government and were based essentially on factors such as education, seniority and occupation ( $\mathrm{Li}$ and Zhao, 2003). As well as wages, workers in SOEs were provided with welfare in the form of, for example, subsidized housing and public medical care. The profitability of enterprises and workers' labor input and productivity did not affect individual wages. Thus, distributions of wages and earnings were fairly equal under the old system (Knight and Song, 2003).

With the process of economic reform and the opening of the economy, the ownership of urban enterprises became more diversified. Foreign, private and individually owned enterprises thrived, which helped to absorb surplus labor and the unemployed. Earnings schemes in non-state-owned enterprises were more market oriented. Hiring decisions and wage setting were determined by enterprises according to worker productivity.

At the same time, enterprise reforms were ongoing within SOEs, which were granted more autonomy in hiring and firing workers and were allowed to reallocate labor to improve efficiency. The wage system of SOEs was also reformed based on hardening budget constraints. Moreover, workers' earnings became better aligned with efficiency, and human capital formation based on education was better rewarded (Meng and Kidd, 1997).

The reforms in SOEs and the development of non-state-owned enterprises increased marketization in the allocation of labor. Large-scale layoffs in the late 1990s intensified the 
reallocation of labor. ${ }^{1}$ According to the National Bureau of Statistics (2005), the number of workers in the state-owned sector as a percentage of all workers in urban China fell from 78.32 in 1978 to 25.34 in 2004 (see Figure 1). ${ }^{2}$

Has economic reform affected the earnings distribution in urban China? To what extent are personal and employment characteristics correlated with earnings inequality? To address these interesting questions, researchers have examined the distribution of earnings from several perspectives. Undoubtedly, the gender earnings gap is a matter of concern. As expected, the gender gap in earnings increased following the dismantling of the planned economy, which compressed earnings (Démurger et al., 2007). Gustafsson and Li (2000) find that the earnings differential between male and female workers increased between 1988 and 1995. However, in the same period, the gender earnings differential that could not be explained by differences in characteristics increased from 52.5\% to 58.9\%. Liu et al. (2008) examine gender earnings differentials in SOEs and collective, private and individually owned enterprises and suggest that human capital is better rewarded in more market-oriented enterprises, which has raised gender earnings differentials.

[Figure 1 about here]

As a substantial component of human capital, education has strong explanatory power for earnings. Returns to education in urban China increased from 3.8\% in 1988 to $5.7 \%$ in 1995 and then to 8.1\% in 1999 (Li and Lee, 1993; Lai, 1999; Li and Ding, 2003). ${ }^{3}$ Returns to education also increase with education levels. For instance, people with tertiary education have a higher return per education year than do those with secondary education. Another important component of human capital is work experience. This affects earnings through two channels in the Chinese context: the cultural heritage of respecting seniority and an increase in the stock of skills through learning-by-doing. It has been shown that the earnings of SOE workers increased with experience between 1981 and 1987 (Meng and Kidd, 1997). However, a recent study indicates that the relationship between earnings and work experience weakened from the mid-1990s (Knight and Song, 2008). Occupation and membership of the Communist Party of China (CPC) also significantly affect earnings. Cadres, professionals and skilled workers have higher wages than do unskilled workers (Knight and Song, 2003; Yueh, 2004).

\footnotetext{
${ }^{1}$ Knight and Yueh (2006) investigate voluntary and involuntary mobility of urban workers in the process of labor market reform.

${ }^{2}$ The state-owned sector includes SOEs, governments and institutions.

${ }^{3}$ Zhang and Zhao (2002) obtained higher estimates of the return to education of $4.7 \%, 7.7 \%$ and $11.5 \%$ in 1988 , 1995 and 1999, respectively.
} 
The mean earnings of workers with CPC membership were $24 \%$ and $17 \%$ higher than those of their non-CPC counterparts in 1995 and 1999, respectively. These differentials reflect both differences in the human capital of CPC and non-CPC workers and the preferential treatment enjoyed by CPC workers (Knight and Song, 2003).

Earnings are also correlated with variables such as ownership, industry and region, the effects of which reflect the extent of segregation of the labor market. If the labor market is fully competitive, workers with the same level of human capital should have similar earnings given ownership, industry and region. The earnings gap between workers in SOEs and other workers is addressed by Zhao (2002), who finds the highest earnings in foreign enterprises, followed by private enterprises, SOEs and then collective enterprises. More interestingly, Zhao (2002) finds that unskilled workers in SOEs have higher earnings than do unskilled workers in foreign enterprises; by contrast, skilled workers' earnings are lower in SOEs than in foreign enterprises. Using data from the China Household Income Project (CHIP), Chen et al. (2005) find that foreign and collective enterprises are at the high and low ends of the earnings distribution, respectively. However, Chen et al. (2005) find that earnings are higher in SOEs than in private enterprises, which contradicts the finding of Zhao (2002). Chen et al. (2005) decompose earnings differentials across sectors with different ownership and confirm the existence of segmentation based on ownership. Gini coefficients of the wage distribution by industry of 0.055 for 1988 and 0.121 for 1997 (Li, 2003) indicate widening earnings differentials across industries. Regional earnings gaps can be interpreted as the result of differences in the extent of marketization. Li and Wang (2005) find that the earnings gap between workers in eastern and western regions widened slightly between 1995 and 2002. The earnings of workers in western regions were up to $64 \%$ and $63 \%$ higher than those of workers in eastern regions in 1995 and 2002.

Our aim is to decompose earnings inequality among workers in urban China based on earnings functions, to quantify the effects of causal factors such as gender, experience and education on earnings inequality and, by comparing the decomposition results for 1988, 1995 and 2002, to examine changes in the effects of the contributing factors.

\section{Regression-based Decomposition Approaches}

Decompositions of inequality indices by population groups and by income sources are commonly applied in the field of income distribution. However, these methods have several drawbacks. To begin with, before decomposition by population groups can proceed, the 
sample must be grouped based on dichotomous variables, such as gender, region or ownership. The effect of continuous variables on income inequality cannot be directly quantified based decomposition by groups (Morduch and Sicular, 2002). Although artificial disaggregation based on continuous variables enables decomposition by groups, the threshold for each category lacks economic justification. Moreover, decomposition by groups based on multiple grouping variables is difficult because the number of cells increases and the number of observations within each cell decreases multiplicatively. Moreover, the grouping variables may not be causal factors of income inequality. Thus, decomposition by population groups reflects the effect on income inequality of underlying causal factors other than the grouping variables (Morduch and Sicular, 2002). Decomposition by income sources is also problematic. While the results from the decomposition indicate the contribution to income inequality of income components, such as wages, property income and transfer income, it cannot quantify the effect on income inequality of causal factors such as gender, education and experience (Fields, 1998).

To overcome the drawbacks of decompositions by groups and sources, regression-based decomposition approaches were developed by Bourguignon et al. (2001), Fields (1998), Morduch and Sicular (2002) and Shorrocks (1999). ${ }^{1}$ Although these approaches are derived from different starting points and are based on different regressions, all aim to estimate the effect of causal factors on income inequality. To facilitate understanding of our decomposition results, we briefly describe the decomposition approaches used in this paper.

Morduch and Sicular (2002) combine regressions of income functions with decomposition by income sources. A linear income function is estimated as follows:

$$
y=\beta_{0}+\beta_{1} X_{1}+\beta_{2} X_{2}+\cdots+\beta_{K} X_{K}+\varepsilon, k=1,2, \cdots, K,
$$

where $y$ is income and the explanatory variables $X_{k}$ include gender, education, experience, occupation, industry and region. $\beta_{k}$ are coefficients to be estimated and $\varepsilon$ is a disturbance term. Based on this income regression, the predicted income based on each causal factor is:

$$
\hat{y}^{k}=\hat{\beta}_{k} x_{k}
$$

\footnotetext{
${ }^{1}$ The approach advocated by Bourguignon et al. (2001) was developed along the lines of the Blinder-Oaxaca decomposition, which is suitable for comparing income inequality in different states (for example, periods, sectors or regions). In this sense, the Bourguignon et al. (2001) approach is a comparative static approach and cannot be applied to analyze dynamic income inequality. In this paper, we aim to decompose earnings inequality in three separate years and then compare the contributions of different factors to inequality. Thus, we choose not to adopt the Bourguignon et al. (2001) approach.
} 
The income attributed to the constant and residual terms are $\hat{y}^{c}=\hat{\beta}_{0}, \hat{y}^{r}=e$, respectively.

If $\hat{y}^{k}$ is treated as one income source, in the framework of Shorrocks (1982), the contribution of $\hat{y}^{k}$ to income inequality is $S\left(\hat{y}^{k}\right)=\sum_{i=1}^{N} a_{i}(y) \hat{y}_{i}^{k} \cdot{ }^{1}$ Similarly, the contributions of the constant and residual terms to inequality are $S\left(\hat{y}^{c}\right)=\sum_{i=1}^{N} a_{i}(y) \hat{\beta}_{0}$ and $S\left(\hat{y}^{r}\right)=\sum_{i=1}^{N} a_{i}(y) e_{i}$, respectively.

Fields (1998) estimates the semilog income function, which is written as $\ln y_{i t}=a_{t}^{\prime} z_{i t}$, where $\ln y$ is the logarithm of income. In addition, $a_{t}=\left[\alpha_{t} \beta_{1 t} \beta_{2 t} \cdots \beta_{J t} 1\right]$ and $z_{i t}=\left[1 X_{i 1 t} X_{i 2 t} \cdots X_{i J t} \varepsilon_{i t}\right]$. Income inequality is then decomposed as:

$$
s_{j}(\ln y)=\frac{\operatorname{cov}\left(a_{j} z_{j}, \ln y\right)}{\sigma^{2}(\ln y)}=\frac{a_{j}^{*} \sigma\left(z_{j}\right) * \operatorname{cor}\left[z_{j}, \ln y\right]}{\sigma(\ln y)},
$$

where $s_{j}(\ln y)$ is the contribution of the $j^{\text {th }}$ income source to inequality indices of income, and $\sum_{j}^{J+2} s_{j}(\ln y)=100 \%$. The deterministic part of the predicted income function, $\sum_{j=1}^{J} s_{j}(\ln y)$, can explain the $R^{2}$ component of the inequality index, with the constant term having no effect on inequality.

The Shorrocks (1999) approach is based on the marginal effects of the causal factors on inequality, each of which measures the change in inequality after isolating a factor. ${ }^{2}$ Because there are many sequences of isolating factors, the marginal effect of a particular factor is not unique. Shorrocks (1999) suggests taking averages of all possible marginal effects to quantify

${ }^{1}$ When several assumptions are satisfied, $I(y)=\sum_{i=1}^{N} a_{i}(y) y_{i}$, where $I(y)$ is the inequality index, $a_{i}(y)$ are weights and $N$ is the number of observations (Shorrocks, 1982). Replacing the sum of the subitems with total income yields $I(y)=\sum_{i=1}^{N} \sum_{j=1}^{M} a_{i}(y) y_{i}{ }^{j}$, where $M$ is the category of income sources. Clearly, the contribution of the income components to inequality is $S\left(y^{j}\right)=\sum_{i=1}^{N} a_{i}(y) y_{i}^{j}$.

${ }^{2}$ Isolating does not mean simply deleting factors. Morduch and Sicular (2002) suggest two ways to isolate factors from inequality: deleting factors, and replacing the means of the factors with the factors themselves. 
the contribution of that factor to inequality. This approach was termed the Shapley decomposition, based on the Shapley value used in cooperative game theory. Wan (2004) extends the Shapley decomposition by explicitly taking the constant and residual terms into account. $^{1}$

The regression-based decomposition approaches described above are based on different premises and all have advantages and disadvantages. The method developed by Fields (1998) only applies to the semilog income function, which decomposes the inequality implied by the log of income rather than income itself. Moreover, the Fields (1998) approach implies that the constant term has no effect on income inequality. Morduch and Sicular (2002) do not properly deal with the constant and residual terms in their decomposition approach either, which is addressed by Wan (2002, 2004). However, Wan (2002, 2004) treats the constant and residual terms differently from the explanatory variables. The effects of the deterministic part on inequality are quantified by applying the Shapley decomposition, whereas the contributions of the constant and residual terms are computed simply by subtracting the contributions of the earnings determinants from total inequality. ${ }^{2}$ All regression-based decomposition approaches have problems in dealing with dummy variables. To be specific, the coefficient of the constant term and those of the explanatory variables are affected by the choice of the reference groups for the dummy variables, on which the decomposition results depend. To address this issue, Yue et al. (2008) advocate a standard transformation of the dummy variables. To implement the standardization, the coefficients of the subgroup variables are multiplied by the subgroup variables to obtain a summed-up variable, from which is subtracted its sample mean. Thus, the sample mean of the summed-up variable is included in the constant term, which no longer affects the decomposition results. When decomposing inequality by using the Fields (1998) and Wan (2004) approaches based on the semilog income function, there is no need to deal with the constant term. Having estimated semilog income functions, Wan (2004) transforms the predicted logarithmic income term to an income term in which the constant term is simply a multiplier of income that has no effect on inequality. In the Fields (1998) framework, the constant term contributes nothing to inequality.

\footnotetext{
${ }^{1}$ See the appendix for discussion of this approach.

${ }^{2}$ Decomposition results obtained from the Morduch and Sicular (2002) approach could be improved by treating the constant and residual terms as proposed by Wan (2004).
} 


\section{Data, Descriptive Statistics and the Earnings Structure}

The data come from the urban survey of CHIP conducted by the Institute of Economics, Chinese Academy of Social Sciences, for the reference years 1988, 1995 and 2002. ${ }^{1}$ The 1988 survey covers Beijing, Shanxi, Liaoning, Jiangsu, Anhui, Hunan, Hubei, Guangdong, Yunnan and Gansu. Sichuan was added to the sample frame in 1995. In 2002, Chongqing was included as a separate province, but it was included as part of Sichuan for the 1995 survey. The surveys cover 9009, 6931 and 6835 urban households in 1988, 1995 and 2002, respectively. Given our focus on earnings, we include only employed persons with complete information on earnings in the sample. The numbers of observations used are 16991, 10852 and 9388 for the reference years 1988, 1995 and 2002, respectively.

Table 1 presents descriptive statistics. Earnings for 1995 and 2002 are deflated by 1988 prices. As Table 1 shows, earnings for male workers increased by 165\% between 1988 and 2002, which is slightly more than the corresponding increase of $161 \%$ for female workers. For the period under study, CPC members experienced faster earnings increases than did nonCPC members. Increases in earnings seem to be linearly correlated with education: more highly educated workers experienced larger increases in earnings. Whereas the earnings of workers without even primary education hardly changed between 1988 and 2002, the earnings of workers with at least a college education increased from 2314 yuan in 1988 to 7156 yuan in 2002.

[Table 1 about here]

Turning to the relationship between work experience and earnings, earnings increased steadily with experience in 1988. However, the earnings-experience curves are clearly Ushaped for 1995 and 2002, similar to those of developed countries, reflecting the increased role of market forces in earnings determination.

Table 1 shows that earnings differ with the ownership status of enterprises. In the three reference years, foreign and collective enterprises had the highest and lowest earnings levels, respectively. Note that, in 1988, the SOEs controlled by local governments had almost the same earnings levels as did SOEs controlled by the central government. However, in 1995 and 2002, the earnings of the former were well below those of the latter, which reflects the increased monopoly power of SOEs controlled by the central government.

\footnotetext{
${ }^{1}$ For a detailed description of the data, see Eichen and Zhang (1993), Khan and Riskin (1998) and Khan and Riskin (2005).
} 
Earnings differentials by occupation are of interest. Managers had the highest earnings in the three reference years, followed by professionals and technicians, while clerks and production workers had the lowest earnings. Managers, professionals and technicians also had the fastest growth in earnings, which increased by nearly 190\% between 1988 and 2002, compared with the $110 \%$ increase in earnings for production workers.

Table 1 also indicates the earnings gaps among industries. Compared with workers in competitive industries (such as manufacturing and catering), those in public services (including governments and institutions) and monopolistic industries (such as telecommunications, finance and insurance) have much higher earnings. Moreover, earnings increased faster in public services and monopolistic industries than in competitive industries. For instance, earnings in the finance and insurance sector increased by 234\% between 1988 and 2002, whereas those in catering only doubled in this period.

Regional earnings gaps are widening, mainly because earnings have increased in eastern regions more rapidly than have those in central and western regions. Take Beijing and Gansu as examples. Average earnings in Beijing were almost the same as those in Gansu in 1988, whereas in 1995, the former were 187\% higher than the latter. Earnings differentials between Beijing and Gansu continued to widening in 2002. Although average earnings in Beijing increased by 280\% between 1988 and 2002, those in Gansu increased by 116\% in the same period.

[Table 2 about here]

The structure of earnings has seen significant changes since wage systems in SOEs were reformed and since nonpublic enterprises with incentive-oriented wage schemes were established. Table 2 shows the change in the components of earnings. It is clear that wage structures were similar in 1988 and 1995. However, there was a striking change in the wage structure in 2002. The share of basic wages in earnings increased from 54\% in 1988 to $81 \%$ in 2002. Accordingly, the shares of bonuses and subsidies fell from 35\% in 1988 to 15\% in 2002 . Incomes from private and individually owned enterprise were playing increasingly important roles in earnings, largely because of the increased number of workers in these enterprises, especially from the mid-1990s when SOEs and urban collective enterprises pursued the policy of laying off workers.

[Table 3 about here] 
[Figure 2 about here]

According to conventional wisdom in China, earnings inequality is increasing. Table 3 confirms this by reporting Gini coefficients for 1988, 1995 and 2002 of 0.235, 0.302 and 0.342, respectively. The Lorenz curves presented in Figure 2 straightforwardly illustrate increasing earnings inequality. The decomposition of earnings inequality by source quantifies the contribution of different components of earnings to inequality. Coupled with the increase in inequality itself and given its share in earnings, the contribution of basic wages to earnings inequality doubled between 1988 and 2002. Bonus payments also contributed to earnings inequality but to a lesser extent. In 1988, subsidies helped to mitigate earnings inequality but exacerbated earnings inequality in 1995 and 2002. While income from private and individually owned enterprises increased earnings inequality in 1988, it reduced inequality in 1995 and 2002. The concentration ratios of income from private and individually owned enterprises are $0.691,0.266$ and -0.063 for 1988,1995 and 2002, respectively.

\section{Earnings Functions}

To decompose inequality indices following Fields (1998), Morduch and Sicular (2002) and Shorrocks (1999), a linear or semilog earning function must be estimated. Table 4 and the appendix table provide estimates of earnings functions. Subject to limitations on space, we only discuss the regression results in Table 4.

\section{[Table 4 about here]}

The estimated semilog earnings function largely confirms the message of the descriptive statistics. After standardization, there is still a widening gender earnings gap. Male workers earned 10\% more than did their female counterparts in 1988, but the gap was $14 \%$ in 2002 . CPC members have increasingly higher earnings than do non-CPC members. After controlling for several characteristics, rates of returns to education increased from $2.6 \%$ in 1988 to $4.7 \%$ in 2002. This result is consistent with the findings of Li and Ding (2003) and Zhang and Zhao (2002) and suggests the gradual marketization of wage determination. Supporting this, the coefficients of work experience and its squared term suggest an ageearnings profile that has an inverted U-shape. That is, earnings increase with age, then peak and thereafter decline. 
Turning to ownership, foreign enterprises have the highest earnings levels, followed by SOEs controlled by central and local governments. It is worth noting that the earnings gap between the two types of SOEs widened in the later period of reform, perhaps because of their different performance levels and degrees of monopoly. In 1988, workers from private and individually owned enterprises had significantly lower earnings than those from the reference group, collective enterprises. However, for 1995 and 2002, there was no earnings differential between these two kinds of enterprises.

Occupation also affects earnings significantly. Unskilled workers are among the lowest earners in all three years. Clearly, managers, professionals and technicians are at the top of the earnings distribution, followed by clerks. Compared with those of production workers, the relative earnings of professionals and technicians, managers and office workers experienced steady increases.

The industry dummy variables are strong predictors of earnings. Compared with most other industries, manufacturing, the reference group, had relatively high earnings in 1988. However, in 1995 and 2002, relative earnings in manufacturing fell, suggesting lower demand for its products. In brief, competitive industries (such as manufacturing and catering) paid lower earnings, whereas industries with monopoly power (such as telecommunications) paid higher earnings.

There are regional gaps in earnings following standardization. Beijing and Guangdong have the highest earnings. In provinces in the eastern region, such as Jiangsu, earnings are higher than in provinces in the central and western regions, such as Henan and Gansu. A matter of concern is that earnings differentials between Beijing, the reference group, and provinces in economically backward regions are widening. For instance, earnings in Gansu were 11\%, 54\% and 68\% lower than in Beijing in 1988, 1995 and 2002, respectively.

\section{Decompositions of Earnings Inequality}

Having estimated linear and semilog earnings functions, we decomposed earnings inequality by using the methods developed by Fields (1998), Morduch and Sicular (2002) and Shorrocks (1999). The results are reported in Tables $5-11$. Table 5 presents decomposition results for inequality in logarithmic earnings, following Fields (1998). Decomposition results of earnings inequality based on the approach advocated by Morduch and Sicular (2002) are 
given in Tables 6-8. ${ }^{1}$ When applying the Shorrocks (1999) approach, predicted logarithmic earnings computed from the semilog earnings function are converted into predicted earnings by taking the antilog. Thus, the decomposition relates to earnings inequality (rather than logarithmic earnings inequality), and the constant term is simply a multiplier that makes no contribution to earnings inequality. Tables 9-11 report the decomposition results based on the Shorrocks (1999) approach.

\section{[Tables 5-11 about here]}

As discussed in Section 3, the three approaches to decomposition do not necessarily yield similar results. However, it is reassuring that the decompositions reported in Tables 511 are similar and all convey a similar message. The contribution of gender to earnings inequality remained relatively unchanged over the period spanned by the three reference years. Although this does not mean that gender made a negligible contribution to earnings inequality, it suggests that other factors made larger contributions. Although the earnings gap between CPC and non-CPC members is widening, the contribution of CPC membership to earnings inequality remained stable over the period.

Work experience played a decreasing role in earnings inequality. In Tables 9-11, the contribution of work experience to the Gini coefficient of earnings decreased from $27.1 \%$ in 1988 to $13.9 \%$ in 1995 and to $5.7 \%$ in 2002. In fact, work experience dominates the distribution of earnings for 1988. A possible explanation is that work experience had a strong effect on earnings while other factors such as gender, education and occupation had relatively small effects on earnings (Knight and Song, 1994). Although earnings differentials among workers with different levels of work experience are not large in absolute terms, work experience did make a significant contribution to inequality in the earnings distribution under the planned economy, given the relatively even distribution of earnings in that period. ${ }^{2}$

Unlike work experience, education played an increasingly important role in earnings inequality. As Tables 9-10 indicate, the contributions of education to the Gini coefficients of earnings are 5.8\%, 6.3\% and $10.6 \%$ for 1988, 1995 and 2002, respectively. The increasingly important role of education suggests a greater role for market forces in the determination of

\footnotetext{
${ }^{1}$ Dummy variables are dealt with by following Yue et al. (2008), so that the decomposition results in Tables 6-8 are not affected by the choice of the reference groups.

${ }^{2}$ Gustafsson et al. (2003) reached a similar conclusion, suggesting that the wage system in China put more weight on work experience than did that of the former USSR.
} 
earnings. Thus, through the process of marketization, individual characteristics that enhance productivity received higher returns. ${ }^{1}$

Ownership status, occupation and industry had increasing effects on earnings inequality, partly because of the reform of wage schemes. Of these three variables, ownership contributed most to earnings inequality, followed by occupation and then industry. However, the differences between these contributions decreased. The rapid development of private, individually owned and foreign enterprises in the early period of reform accounted for much of the increase in earnings inequality, although nonpublic enterprises were rare th that time. As SOE reforms progressed and efficiency-based wage schemes became predominant, the contribution of ownership status to earnings inequality declined. Similarly, the increasing role of industry in explaining earnings inequality may reflect the tightening of budget constraints. When SOEs were the dominant form of enterprise, they paid earnings that were independent of industry profitability. SOEs in low-profitability industries received subsidies to enable them to maintain a certain level of earnings, and SOEs in high-profitability industries were only allowed to vary earnings within certain limits. Following the tightening of SOE budget constraints and the expansion of nonpublic enterprises, earnings related more closely to firm performance. Thus, because industry influences earnings through profitability, it follows that industry has a greater effect on earnings inequality.

The provincial dummy variables were (after work experience) the second most important contributor to earnings inequality in 1988. In 1995 and 2002, provincial dummies were the most important contributor. The changing role of the provinces reflects provincial differences in economic performance and the process of marketization and implies the emergence of labor market segregation (Knight et al., 2001; Li and Wang, 2005). Increased worker mobility between regions can be expected to reduce earnings inequality in urban China.

\section{Concluding Remarks}

Earnings inequality in urban China is increasing. To explain this, in this paper, using household survey data from the China Household Income Project for the reference years 1988, 1995 and 2002, we decomposed earnings inequality by applying the methods developed by Fields (1998), Morduch and Sicular (2002) and Shorrocks (1999).

\footnotetext{
${ }^{1}$ The distribution of schooling remained relatively unchanged across the three reference years. According to our computations, the Gini coefficients of schooling are 0.1462, 0.1511 and 0.1422 for 1988, 1995 and 2002, respectively.
} 
Our decomposition results suggest that the contributions of gender and membership of the Communist Party of China to earnings inequality remained fairly stable over the period spanned by the reference years. Work experience made the greatest contribution to earnings inequality in 1988, but this contribution diminished greatly in 1995 and 2002. At the same time, education differences made an increasingly important contribution to earnings inequality. Occupational differences also explain rising earnings inequality. The changing roles of work experience, education and occupation imply that personal characteristics associated with higher productivity were better rewarded following the reform of wage systems, which increased incentives for workers and promoted economic growth through enhanced efficiency.

Because the urban labor market remains in its infancy, segmentation persists. Barriers to labor mobility between enterprises of different ownership status, industries and regions remain, which is to blame for rising earnings inequality.

Earnings inequality caused by labor market segmentation is a form of unfair inequality, which requires policy measures. Although ownership status, industry and region are all segmentation factors, they have different effects on earnings inequality, as discussed above. Thus, policies designed to lower earnings inequality by reducing segmentation should be prioritized. Because regional effects are currently the largest contributor to earnings inequality, attenuating regional segmentation is the most effective way to reduce earnings inequality. Regulating industries that have monopoly power by restricting their scope to raise earnings would also help to reduce earnings inequality. By reducing segmentation, these policy measures can be expected to enhance efficiency as well as increase earnings equality. 


\section{References}

Bourguignon, François, Martin Fournier and Marc Gurgand, 2001, Fast Development with a Stable Income Distribution: Taiwan, 1979-94, Review of Income and Wealth, Vol. 47, No. 2, June, pp. 139-163.

Chen, Yi, Sylvie Démurger and Martin Fournier, 2005, Earnings Differentials and Ownership Structure in Chinese Enterprises, Economic Development and Cultural Change, Vol. 53, No. 4, July, pp. 933-958.

Démurger, Sylvie, Martin Fournier, Shi Li and Zhong Wei, 2006, Economic Liberalization with Rising Segmentation in China’s Urban Labor Market, Asian Economic Papers, Vol. 5, No. 3, pp. 58-101.

Démurger, Sylvie, Martin Fournier and Yi Chen, 2007, The Evolution of Gender Wage Gaps and Discrimination in Urban China: 1988-95, The Developing Economies, Vol. 45, Issue 1, pp. 97-121.

Eichen, Marc and Ming Zhang, 1993, The 1988 Household Sample Survey - Data Description and Availability, in Keith Griffin and Renwei Zhao (eds.), The Distribution of Income in China, pp. 331-346, London: Macmillan Press.

Fields, Gary, 1998, Accounting for Differences in Income Inequality, mimeo, Cornell University.

Gustafsson, Björn and Shi Li, 2001, The Anatomy of Rising Earnings Inequality in Urban China, Journal of Comparative Economics, Vol. 29, pp. 118-135.

Gustafsson, Björn and Shi Li, 2000, Economic Transformation and the Gender Earnings Gap in Urban China, Journal of Population Economics, Vol. 13, pp. 305-329.

Gustafsson, Björn, Shi Li, Ludmila Nivorozhkina and Katerina Katz, 2003, Rubles and Yuan: Wage Functions for Urban China and Russia at the End of the 80s, Economic Development and Cultural Change, Vol. 50, No. 1, pp. 1-17.

Juhn, Chinhui, Kevin Murphy and Brooks Pierce, 1991, Accounting for the Slowdown in Black-White Wage Convergence, in Marvin Kosters (ed.), Workers and Their Wages: Changing Patterns in the United States, Washington: American Enterprise Institute Press, pp. 107-143.

Khan, Aziz and Carl Riskin, 2005, Household Income and its Distribution in China, 1995 and 2002, China Quarterly, Vol. 182, pp. 356-384. 
Khan, Azizur, R. and Carl Riskin, 1998, Income Inequality in China: Composition, Distribution and Growth of Household Income, 1988 to 1995, China Quarterly, Vol. 154, pp. 221-253.

Knight, John and Lina Song, 1994, Why Urban Wages Differ in China, in Keith Griffin and Renwei Zhao (eds.), The Distribution of Income in China, pp. 216-284, London: Macmillan Press.

Knight, John and Lina Song, 2003, Increasing Urban Wage Inequality in China: Extent, Elements and Evaluation, Economics of Transition, Vol. 11, No. 4, pp. 597-619.

Knight, John and Lina Song, 2008, China’s Emerging Urban Wage Structure, 1995-2002, in Björn Gustafsson, Shi Li and Terry Sicular (eds.), Inequality and Public Policy in China, pp. 221-242, Cambridge: Cambridge University Press.

Knight, John and Linda Yueh, 2006, Job Mobility of Residents and Migrants in Urban China, in Shi Li and Hiroshi Sato (eds.), Unemployment, Inequality, and Poverty in Urban China, pp. 236-260, London: Routledge.

Knight, John, Shi Li and Renwei Zhao, 2001, A Spatial Analysis of Wages and Incomes in Urban China: Divergent Means, Convergent Inequality, in Carl Riskin, Renwei Zhao and Shi Li (eds.), China's Retreat from Equality: Income Distribution and Economic Transition, pp. 133-166, New York: M.E. Sharpe.

Lai, Desheng, 1999, Education, Labor Markets and Income Distribution, in Renwei Zhao and Keith Griffin (eds.), Research on Household Income Distribution in China, pp. 451-474, Beijing: Publishing House of Chinese Social Sciences, in Chinese.

Li, Shi, 2003, Literature Review on Income Distribution in China: Retrospect and Prospect, Economics (Quarterly), Vol. 2, No. 2, pp. 379-404, in Chinese.

Li, Shi and Björn Gustafsson, 2008, Unemployment, Earlier Retirement and Changes in the Gender Income Gap in Urban China, 1995-2002, in Björn Gustafsson, Shi Li and Terry Sicular (eds.), Inequality and Public Policy, pp. 242-266, Cambridge: Cambridge University Press.

Li, Shi and Sai Ding, 2003, Changes in Returns to Education in Urban China, China Social Sciences, No. 6, pp. 58-72, in Chinese.

Li, Shi and Travers, Lee, 1994, Estimates of Returns to Education in China, in Renwei Zhao and Keith Griffin (eds.), Research on Household Income Distribution in China, Beijing: Publishing House of Chinese Social Sciences, in Chinese.

Li, Shi and Yake Wang, 2005, Empirical Analysis of the Earnings Gap between Eastern and Western Regions in China, Management World, No. 6, pp. 16-26, in Chinese. 
Li, Shi and Zhao, Yaohui, 2003, The Decline of In-kind Wage Payments in Urban China, Journal of Chinese Economic and Business Studies, Vol. 1, No. 2, pp. 245-258.

Liu, Pak-Wai, Xin Meng and Junsen Zhang, 2000, Sectoral Gender Wage Differentials and Discrimination in the Transitional Chinese Economy, Journal of Population Economics, Vol. 13, Issue 2, pp. 331-352.

Meng, Xin and Michael P. Kidd, 1997, Labor Market Reform and the Changing Structure of Wage Determination in China's State Sector during the 1980s, Journal of Comparative Economics, Vol. 25, Issue 3, pp. 403-421.

Morduch, Jonathan and Terry Sicular, 2002, Rethinking Inequality Decomposition, with Evidence from Rural China, Economic Journal, Vol. 112, pp. 93-106.

National Bureau of Statistics, 2005, China Statistical Yearbook, Beijing: China Statistical Press.

Shorrocks, Anthony. F., 1982, Inequality Decomposition by Factor Components, Econometrica, Vol. 50, No. 1, pp. 193-201.

Shorrocks, Anthony. F., 1999, Decomposition Procedures for Distributional Analysis: A Unified Framework Based on the Shapley Value, unpublished manuscript, Department of Economics, University of Essex.

Wan, Guanghua, 2002, Regression-based Inequality Decomposition: Pitfalls and a Solution Procedure, WIDER Discussion Paper No. 2002/101, UNU-WIDER.

Wan, Guanghua, 2004, Accounting for Income Inequality in Rural China: A Regressionbased Approach, Journal of Comparative Economics, Vol. 32, Issue 2, pp. 348-363.

Yue, Ximing, Terry Sicular, Shi Li and Björn Gustafsson, 2008, Explaining Incomes and Inequality in China, in Björn Gustafsson, Shi Li and Terry Sicular (eds.), Inequality and Public Policy, pp. 88-117, Cambridge: Cambridge University Press.

Yueh, Linda, 2004, Wage Reforms in China during the 1990s, Asian Economic Journal, Vol. 18, No. 2, pp. 149-164.

Zhang, Junsen and Yaohui Zhao, 2002, Economic Returns to Schooling in Urban China, 1988-1999, presented at the 5th Annual NBER-CCER Conference, June 30-July 2, Beijing, 2002.

Zhao, Yaohui, 2002, Earnings Differentials between State and Non-state Enterprises in Urban China, Pacific Economic Review, Vol. 7, No. 1, pp. 181-197. 
Figure 1. Number of workers in state-owned units as a percentage of all workers in urban China

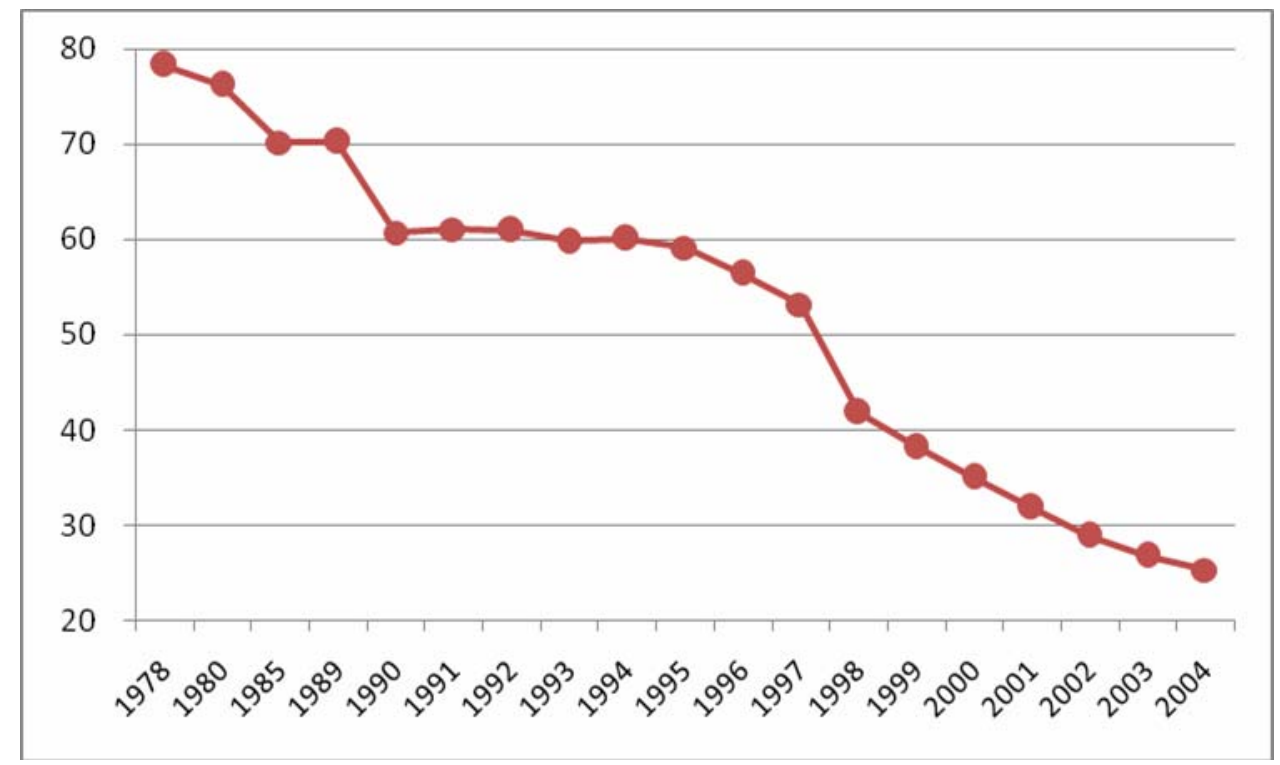

Source: National Bureau of Statistics (2005)

Figure 2. Lorenz curves of earnings for 1988, 1995 and 2002

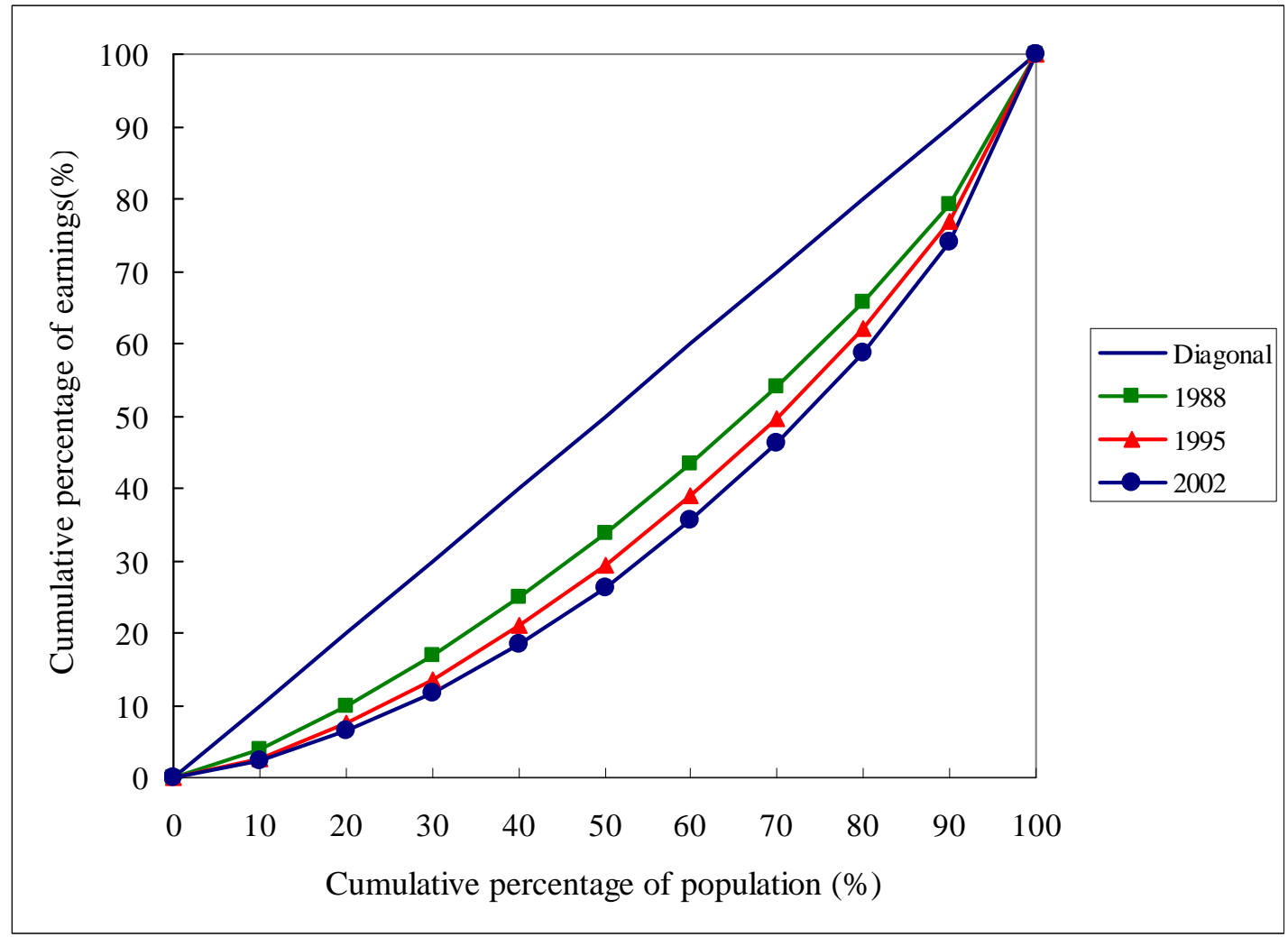


Table 1. Descriptive statistics

\begin{tabular}{|c|c|c|c|c|c|c|}
\hline & 1988 & & 1995 & & 2002 & \\
\hline & $\begin{array}{l}\text { Proportion } \\
\text { (\%) }\end{array}$ & $\begin{array}{l}\text { Earnings } \\
\text { (yuan) }\end{array}$ & $\begin{array}{l}\text { Proportion } \\
\text { (\%) }\end{array}$ & $\begin{array}{l}\text { Earnings } \\
\text { (yuan) }\end{array}$ & $\begin{array}{l}\text { Proportion } \\
\text { (\%) }\end{array}$ & $\begin{array}{c}\text { Earnings } \\
\text { (yuan) }\end{array}$ \\
\hline Male & 52.57 & 1989.08 & 52.85 & 2991.71 & 55.63 & 5263.98 \\
\hline Female & 47.43 & 1656.20 & 47.15 & 2489.81 & 44.37 & 4322.05 \\
\hline CPC members & 24.20 & 2217.41 & 25.22 & 3361.82 & 29.87 & 5960.70 \\
\hline Non-CPC members & 75.80 & 1707.89 & 74.78 & 2550.41 & 70.13 & 4371.40 \\
\hline \multicolumn{7}{|l|}{ Education } \\
\hline College and above & 6.34 & 2313.59 & 7.86 & 3567.43 & 10.76 & 7155.70 \\
\hline Poly-tech college & 6.85 & 1964.79 & 15.60 & 3150.51 & 23.65 & 5553.30 \\
\hline Senior middle school & 35.77 & 1788.62 & 41.29 & 2701.95 & 40.71 & 4521.37 \\
\hline Junior middle school & 38.73 & 1764.59 & 30.10 & 2495.67 & 22.38 & 3768.85 \\
\hline Primary school & 10.31 & 1873.31 & 4.86 & 2291.76 & 2.35 & 3214.74 \\
\hline Below primary & 2.00 & 1677.04 & 0.29 & 1717.16 & 0.16 & 1920.20 \\
\hline \multicolumn{7}{|l|}{ Work experience } \\
\hline$\leq 10$ & 20.40 & 1260.67 & 16.46 & 2091.26 & 13.54 & 4185.68 \\
\hline $11-20$ & 28.13 & 1795.89 & 27.00 & 2611.60 & 25.55 & 4843.04 \\
\hline $21-30$ & 31.39 & 2029.97 & 36.73 & 3010.93 & 34.75 & 4892.11 \\
\hline $31-40$ & 16.28 & 2155.77 & 16.96 & 3104.03 & 22.98 & 5176.38 \\
\hline$\geq 41$ & 3.79 & 2123.01 & 2.86 & 2573.77 & 3.18 & 4793.11 \\
\hline \multicolumn{7}{|l|}{ Ownership } \\
\hline Central SOEs & 39.07 & 1988.00 & 26.86 & 3119.12 & 45.88 & 5610.94 \\
\hline Local SOEs & 39.49 & 1821.65 & 55.10 & 2734.24 & 20.23 & 4399.11 \\
\hline Collective enterprises & 20.46 & 1543.01 & 15.55 & 2139.22 & 7.32 & 3317.16 \\
\hline $\begin{array}{l}\text { Private and } \\
\text { individually owned }\end{array}$ & 0.22 & 1886.30 & 0.73 & 2446.97 & 9.66 & 3422.19 \\
\hline Foreign enterprises & 0.35 & 2842.11 & 1.27 & 3733.04 & 2.36 & 6377.01 \\
\hline Other & 0.41 & 1297.23 & 0.50 & 2598.00 & 14.55 & 4521.50 \\
\hline \multicolumn{7}{|l|}{ Occupation } \\
\hline $\begin{array}{l}\text { Professionals and } \\
\text { technicians }\end{array}$ & 16.31 & 2055.15 & 22.59 & 3171.05 & 22.48 & 5911.17 \\
\hline Managers & 6.72 & 2329.19 & 11.82 & 3503.71 & 11.21 & 6710.60 \\
\hline Clerks & 23.91 & 1917.90 & 21.25 & 2717.59 & 21.33 & 5041.38 \\
\hline Production workers & 52.99 & 1660.46 & 39.14 & 2382.05 & 42.72 & 3786.03 \\
\hline Other & 0.08 & 1539.59 & 5.20 & 2205.42 & 2.27 & 3213.04 \\
\hline \multicolumn{7}{|l|}{ Industry } \\
\hline $\begin{array}{l}\text { Agriculture, forestry, } \\
\text { husbandry, fishing }\end{array}$ & 0.99 & 1775.77 & 1.70 & 2978.54 & 1.27 & 4689.13 \\
\hline Manufacturing & 43.09 & 1759.41 & 41.54 & 2573.42 & 26.52 & 4120.44 \\
\hline $\begin{array}{l}\text { Mining and geological } \\
\text { prospecting }\end{array}$ & 3.98 & 1812.64 & 1.03 & 2821.70 & 5.90 & 5055.93 \\
\hline Construction & 3.46 & 1841.68 & 2.90 & 2847.00 & 3.36 & 5231.40 \\
\hline $\begin{array}{l}\text { Transportation, post } \\
\text { and } \\
\text { telecommunications }\end{array}$ & 6.83 & 2014.41 & 5.10 & 3055.29 & 7.88 & 5232.06 \\
\hline $\begin{array}{l}\text { Commerce, trade, } \\
\text { restaurants and catering }\end{array}$ & 14.16 & 1835.05 & 14.43 & 2439.18 & 10.15 & 3670.67 \\
\hline $\begin{array}{l}\text { Real estate, public } \\
\text { utilities }\end{array}$ & 2.34 & 1656.86 & 3.90 & 2835.09 & 10.68 & 3980.85 \\
\hline
\end{tabular}




\begin{tabular}{|c|c|c|c|c|c|c|}
\hline $\begin{array}{l}\text { Health, physical culture } \\
\text { and social welfare }\end{array}$ & 4.68 & 1890.45 & 4.68 & 3123.53 & 5.35 & 5723.72 \\
\hline $\begin{array}{l}\text { Education, culture and } \\
\text { arts }\end{array}$ & 7.45 & 1966.36 & 7.34 & 3105.26 & 9.58 & 6100.73 \\
\hline $\begin{array}{l}\text { Scientific research and } \\
\text { technical services }\end{array}$ & 2.10 & 2051.26 & 2.45 & 3275.42 & 1.86 & 7371.91 \\
\hline Finance, insurance & 1.57 & 1740.75 & 2.02 & 3202.14 & 2.82 & 5817.56 \\
\hline $\begin{array}{l}\text { Government and party } \\
\text { organs, social } \\
\text { organizations }\end{array}$ & 8.63 & 1940.99 & 12.15 & 3007.03 & 12.62 & 5750.52 \\
\hline Other & 0.72 & 1460.35 & 0.75 & 2765.35 & 2.00 & 4583.41 \\
\hline \multicolumn{7}{|l|}{ Provinces } \\
\hline Beijing & 4.56 & 1926.75 & 6.81 & 3775.81 & 8.76 & 7319.96 \\
\hline Shanxi & 10.70 & 1617.28 & 9.68 & 2156.52 & 8.52 & 4022.53 \\
\hline Liaoning & 10.94 & 1770.78 & 10.83 & 2468.19 & 10.85 & 4371.26 \\
\hline Jiangsu & 13.38 & 1730.01 & 10.89 & 3015.38 & 9.92 & 5009.34 \\
\hline Anhui & 9.75 & 1682.58 & 7.26 & 2175.52 & 6.76 & 4209.36 \\
\hline Henan & 11.28 & 1488.41 & 8.53 & 2086.65 & 9.20 & 3517.45 \\
\hline Hubei & 11.07 & 1731.26 & 10.24 & 2614.36 & 10.17 & 4183.16 \\
\hline Guangdong & 11.77 & 2652.49 & 8.67 & 4921.44 & 9.26 & 7544.94 \\
\hline Sichuan & - & - & - & - & 4.21 & 5022.60 \\
\hline Chongqing & - & - & 11.79 & 2573.27 & 8.04 & 4096.86 \\
\hline Yunnan & 10.30 & 1908.93 & 9.77 & 2542.48 & 8.70 & 4596.88 \\
\hline Gansu & 6.24 & 1802.23 & 5.53 & 2013.80 & 5.60 & 3889.45 \\
\hline Work experience & & 20.79 & & 21.77 & & 23.05 \\
\hline Work experience squared & & 553.36 & & 579.02 & & 638.25 \\
\hline Schooling & & 10.50 & & 10.77 & & 11.53 \\
\hline Earnings (yuan) & & 1831.19 & & 2755.05 & & 4846.09 \\
\hline Logarithmic earnings & & 7.41 & & 7.74 & & 8.27 \\
\hline Observations & & 16691 & & 10852 & & 9388 \\
\hline
\end{tabular}

Note: earnings are in 1988 prices. 
Table 2. The structure of earnings

\begin{tabular}{ccccccc}
\hline & \multicolumn{3}{c}{1988} & \multicolumn{3}{c}{2002} \\
\cline { 2 - 7 } & $\begin{array}{c}\text { Proportion } \\
(\%)\end{array}$ & $\begin{array}{c}\text { Amount } \\
\text { (yuan) }\end{array}$ & $\begin{array}{c}\text { Proportion } \\
(\%)\end{array}$ & $\begin{array}{c}\text { Amount } \\
\text { (yuan) }\end{array}$ & $\begin{array}{c}\text { Proportion } \\
(\%)\end{array}$ & $\begin{array}{c}\text { Amount } \\
\text { (yuan) }\end{array}$ \\
\hline Basic wage & 54.45 & 997.08 & 58.23 & 1604.16 & 81.37 & 3943.04 \\
Bonus & 18.92 & 346.55 & 15.23 & 419.50 & 9.26 & 448.90 \\
Subsidy & 16.51 & 302.40 & 16.58 & 456.80 & 6.03 & 292.07 \\
Income from & 0.12 & 2.16 & 0.54 & 14.83 & 1.17 & 56.76 \\
operations & 9.99 & 183.00 & 9.43 & 259.76 & 2.17 & 105.33 \\
Other & & & & & & \\
\hline
\end{tabular}

Note: earnings and earnings components are in 1988 prices.

Table 3. Decomposition of earnings inequality by source

\begin{tabular}{ccccccc}
\hline & 1988 & \multicolumn{5}{c}{1995} \\
\cline { 2 - 7 } & $\begin{array}{c}\text { Concentration } \\
\text { ratio }\end{array}$ & $\begin{array}{c}\text { Contribution } \\
(\%)\end{array}$ & $\begin{array}{c}\text { Concentration } \\
\text { ratio }\end{array}$ & $\begin{array}{c}\text { Contribution } \\
(\%)\end{array}$ & $\begin{array}{c}\text { Concentration } \\
\text { ratio }\end{array}$ & $\begin{array}{c}\text { Contribution } \\
(\%)\end{array}$ \\
\hline $\begin{array}{c}\text { Basic } \\
\text { wage }\end{array}$ & 0.1571 & 36.34 & 0.2219 & 42.75 & 0.3071 & 73.12 \\
$\begin{array}{c}\text { Bonus } \\
\text { Subsidy }\end{array}$ & 0.4091 & 32.89 & 0.5242 & 26.40 & 0.5791 & 15.70 \\
$\begin{array}{c}\text { Income } \\
\text { from }\end{array}$ & 0.2004 & 14.05 & 0.3255 & 17.85 & 0.5323 & 9.39 \\
$\begin{array}{c}\text { operations } \\
\text { Other }\end{array}$ & 0.6914 & 0.35 & 0.2664 & 0.47 & -0.0634 & -0.22 \\
Gini & 0.3857 & 16.37 & 0.4016 & 12.53 & 0.3175 & 2.02 \\
\hline
\end{tabular}


Table 4. Estimated earnings functions

\begin{tabular}{|c|c|c|c|c|c|c|}
\hline Logarithmic earnings & & & & & 200 & \\
\hline Male & 0.095 & $* * *$ & 0.144 & $* * *$ & 0.138 & $* * *$ \\
\hline $\mathrm{CPC}$ & 0.061 & $* * *$ & 0.079 & $* * *$ & 0.084 & $* * *$ \\
\hline Work experience & 0.042 & $* * *$ & 0.068 & $* * *$ & 0.030 & $* * *$ \\
\hline Work experience squared & -0.001 & $* * *$ & -0.001 & $* * *$ & -0.0004 & $* * *$ \\
\hline Schooling & 0.026 & $* * *$ & 0.027 & $* * *$ & 0.047 & $* * *$ \\
\hline Central SOEs & 0.189 & $* * *$ & 0.362 & $* * *$ & 0.326 & $* * *$ \\
\hline Local SOEs & 0.107 & $* * *$ & 0.184 & $* * *$ & 0.168 & $* * *$ \\
\hline Collective enterprises & - & & - & & - & \\
\hline $\begin{array}{l}\text { Private and individually owned } \\
\text { enterprises }\end{array}$ & -0.244 & $* * *$ & 0.028 & & 0.037 & \\
\hline Foreign enterprises & 0.301 & $* * *$ & 0.444 & $* * *$ & 0.462 & $* * *$ \\
\hline Other & -0.298 & $* * *$ & 0.114 & & 0.222 & $* * *$ \\
\hline Professionals and technicians & 0.071 & $* * *$ & 0.186 & $* * *$ & 0.209 & $* * *$ \\
\hline Managers & 0.099 & $* * *$ & 0.179 & $* * *$ & 0.232 & $* * *$ \\
\hline Clerks & 0.050 & $* * *$ & 0.089 & $* * *$ & 0.121 & $* * *$ \\
\hline Production workers & - & & - & & - & \\
\hline Other & 0.057 & & -0.020 & & -0.253 & $* * *$ \\
\hline $\begin{array}{l}\text { Agriculture, forestry, husbandry, } \\
\text { fishing }\end{array}$ & -0.035 & & -0.055 & & 0.049 & \\
\hline Manufacturing & - & & - & & - & \\
\hline $\begin{array}{l}\text { Mining and geological } \\
\text { prospecting }\end{array}$ & 0.041 & $* * *$ & -0.006 & & 0.181 & $* * *$ \\
\hline Construction & 0.007 & & 0.024 & & 0.019 & \\
\hline $\begin{array}{l}\text { Transportation, post and } \\
\text { telecommunications }\end{array}$ & 0.009 & & 0.071 & $* * *$ & 0.152 & $* * *$ \\
\hline $\begin{array}{l}\text { Commerce, trade, restaurants } \\
\text { and catering }\end{array}$ & -0.013 & & -0.058 & $* * *$ & -0.121 & $* * *$ \\
\hline Real estate, public utilities & -0.093 & $* * *$ & -0.047 & & -0.097 & $* * *$ \\
\hline $\begin{array}{l}\text { Health, physical culture and } \\
\text { social welfare }\end{array}$ & -0.045 & $* * *$ & 0.069 & $* *$ & 0.125 & $* * *$ \\
\hline Education, culture and arts & -0.049 & $* * *$ & 0.062 & $* * *$ & 0.130 & $* * *$ \\
\hline $\begin{array}{l}\text { Scientific research and technical } \\
\text { services }\end{array}$ & -0.032 & $*$ & 0.042 & & 0.193 & $* * *$ \\
\hline Finance, insurance & -0.069 & $* * *$ & 0.180 & $* * *$ & 0.139 & $* * *$ \\
\hline $\begin{array}{l}\text { Government and party organs, } \\
\text { social organizations }\end{array}$ & -0.088 & $* * *$ & -0.003 & & 0.057 & $* *$ \\
\hline Other & -0.188 & $* * *$ & -0.137 & $* *$ & -0.029 & \\
\hline Beijing & - & & - & & - & \\
\hline Shanxi & -0.215 & $* * *$ & -0.503 & $* * *$ & -0.640 & $* * *$ \\
\hline Liaoning & -0.019 & & -0.349 & $* * *$ & -0.477 & $* * *$ \\
\hline Jiangsu & -0.008 & & -0.086 & $* * *$ & -0.365 & $* * *$ \\
\hline Anhui & -0.108 & $* * *$ & -0.443 & $* * *$ & -0.568 & $* * *$ \\
\hline Henan & -0.241 & $* * *$ & -0.512 & $* * *$ & -0.707 & $* * *$ \\
\hline Hubei & -0.091 & $* * *$ & -0.295 & $* * *$ & -0.561 & $* * *$ \\
\hline Guangdong & 0.289 & $* * *$ & 0.330 & $* * *$ & 0.032 & \\
\hline Sichuan & N.A. & & -0.301 & $* * *$ & -0.430 & $* * *$ \\
\hline Chongqing & N.A. & & N.A. & & -0.529 & $* * *$ \\
\hline Yunnan & 0.010 & & -0.334 & $* * *$ & -0.474 & $* * *$ \\
\hline Gansu & -0.109 & $* * *$ & -0.544 & $* * *$ & -0.677 & $* * *$ \\
\hline
\end{tabular}




\begin{tabular}{|c|c|c|c|c|c|c|}
\hline Constant & 6.447 & $* * *$ & 6.634 & $* * *$ & 7.280 & $* * *$ \\
\hline Adj. $\mathrm{R}^{2}$ & 0.4338 & & 0.3219 & & 0.3673 & \\
\hline F-Value & 366.39 & & 144.07 & & 148.28 & \\
\hline Observations & 16691 & & 10852 & & 9388 & \\
\hline
\end{tabular}

Note: $* * *, * *, *$ indicate statistical significance at the $1 \%, 5 \%$ and $10 \%$ levels, respectively.

N.A. indicates that the province was not surveyed. 
Table 5. Decompositions of earnings inequality based on the Fields (1998) approach

\begin{tabular}{cccl}
\hline & 1988 & 1995 & \multicolumn{1}{c}{2002} \\
\hline Male & 0.0219 & 0.0163 & 0.016 \\
CPC & 0.0163 & 0.0102 & 0.0136 \\
Work experience & 0.2157 & 0.0807 & 0.0243 \\
Schooling & 0.0167 & 0.0218 & 0.0563 \\
Ownership & 0.0403 & 0.0363 & 0.0545 \\
Occupation & 0.0213 & 0.0309 & 0.0543 \\
Industry & -0.0016 & 0.0083 & 0.0381 \\
Province & 0.1045 & 0.1196 & 0.1129 \\
Residual & 0.5650 & 0.6759 & 0.6302 \\
Total & 1.00 & & 1.00 \\
\hline
\end{tabular}

Table 6. Decompositions of earnings inequality based on the Morduch and Sicular approach for 1988

\begin{tabular}{|c|c|c|c|c|c|c|}
\hline & Gini & (\%) & Theil & $(\%)$ & $\mathrm{CV}^{2}$ & $(\%)$ \\
\hline Male & 0.0064 & 2.72 & -0.0006 & -0.54 & 0.0043 & 1.44 \\
\hline СРC & 0.0067 & 2.83 & 0.0026 & 2.45 & 0.0044 & 1.48 \\
\hline Work experience & 0.0469 & 19.91 & -0.0077 & -7.24 & 0.0290 & 9.74 \\
\hline Schooling & 0.0044 & 1.88 & -0.0228 & -21.54 & 0.0031 & 1.04 \\
\hline Ownership & 0.0085 & 3.59 & 0.0063 & 5.97 & 0.0061 & 2.07 \\
\hline Occupation & 0.0048 & 2.02 & 0.0034 & 3.18 & 0.0030 & 0.99 \\
\hline Industry & -0.0008 & -0.33 & -0.0005 & -0.46 & -0.0003 & -0.10 \\
\hline Province & 0.0323 & 13.73 & 0.0247 & 23.38 & 0.0304 & 10.23 \\
\hline Constant & 0 & 0 & -0.0245 & -23.14 & 0 & 0 \\
\hline Residual & 0.1263 & 53.66 & 0.1247 & 117.94 & 0.2175 & 73.10 \\
\hline Total & 0.2354 & 100 & 0.1057 & 100 & 0.2975 & 100 \\
\hline
\end{tabular}


Table 7. Decompositions of earnings inequality based on the Morduch and Sicular approach for 1995

\begin{tabular}{|c|c|c|c|c|c|c|}
\hline & Gini & $(\%)$ & Theil & $(\%)$ & $\mathrm{CV}^{2}$ & $(\%)$ \\
\hline Male & 0.0051 & 1.70 & -0.0045 & -2.81 & 0.0047 & 1.23 \\
\hline CPC & 0.0047 & 1.55 & 0.0011 & 0.68 & 0.0041 & 1.09 \\
\hline Work experience & 0.0222 & 7.34 & -0.0616 & -38.43 & 0.0177 & 4.69 \\
\hline Schooling & 0.0091 & 3.00 & -0.0420 & -26.19 & 0.0080 & 2.13 \\
\hline Ownership & 0.0144 & 4.75 & 0.0141 & 8.78 & 0.0116 & 3.07 \\
\hline Occupation & 0.0108 & 3.58 & 0.0112 & 6.99 & 0.0094 & 2.49 \\
\hline Industry & 0.0033 & 1.09 & 0.0031 & 1.91 & 0.0033 & 0.86 \\
\hline Province & 0.0656 & 21.71 & 0.0663 & 41.40 & 0.0834 & 22.05 \\
\hline Constant & 0 & 0 & -0.0321 & -20.03 & 0 & 0 \\
\hline Residual & 0.1671 & 55.28 & 0.2046 & 127.70 & 0.2359 & 62.39 \\
\hline Total & 0.3023 & 100 & 0.1602 & 100 & 0.3781 & 100 \\
\hline
\end{tabular}

Table 8. Decompositions of earnings inequality based on the Morduch and Sicular approach for 2002

\begin{tabular}{|c|c|c|c|c|c|c|}
\hline & Gini & (\%) & Theil & (\%) & $\mathrm{CV}^{2}$ & (\%) \\
\hline Male & 0.0057 & 1.68 & -0.0076 & -3.75 & 0.0057 & 1.12 \\
\hline $\mathrm{CPC}$ & 0.0053 & 1.55 & 0.0010 & 0.51 & 0.0053 & 1.05 \\
\hline Work experience & 0.0076 & 2.24 & -0.0645 & -31.95 & 0.0069 & 1.36 \\
\hline Schooling & 0.0237 & 6.94 & -0.0867 & -42.95 & 0.0251 & 4.96 \\
\hline Ownership & 0.0156 & 4.55 & 0.0169 & 8.37 & 0.0143 & 2.82 \\
\hline Occupation & 0.0226 & 6.60 & 0.0252 & 12.50 & 0.0235 & 4.65 \\
\hline Industry & 0.0155 & 4.54 & 0.0169 & 8.36 & 0.0148 & 2.92 \\
\hline Province & 0.0516 & 15.11 & 0.0591 & 29.30 & 0.0688 & 13.59 \\
\hline Constant & 0 & 0 & -0.0076 & -3.75 & 0 & 0 \\
\hline Residual & 0.1942 & 56.81 & 0.2490 & 123.37 & 0.3416 & 67.52 \\
\hline Total & 0.3418 & 100 & 0.2019 & 100 & 0.5059 & 100 \\
\hline
\end{tabular}


Table 9. Decompositions of earnings inequality based on the Shorrocks approach for 1988

\begin{tabular}{|c|c|c|c|c|c|c|c|c|c|c|}
\hline & Gini & $\%$ & Atkinson & $\%$ & Theil & $\%$ & MLD & $\%$ & GE(2) & $\%$ \\
\hline Male & 0.0103 & 4.39 & 0.0022 & 2.28 & 0.0022 & 2.12 & 0.0022 & 2.22 & 0.0023 & 1.58 \\
\hline СРС & 0.0063 & 2.67 & 0.0016 & 1.67 & 0.0016 & 1.55 & 0.0016 & 1.64 & 0.0017 & 1.14 \\
\hline $\begin{array}{l}\text { Work } \\
\text { experience }\end{array}$ & 0.0638 & 27.08 & 0.0199 & 20.84 & 0.0189 & 17.85 & 0.0204 & 20.25 & 0.0182 & 12.26 \\
\hline Schooling & 0.0137 & 5.82 & 0.0019 & 2.01 & 0.0022 & 2.07 & 0.0019 & 1.93 & 0.0025 & 1.68 \\
\hline Ownership & 0.0170 & 7.20 & 0.0039 & 4.08 & 0.0039 & 3.68 & 0.0040 & 3.97 & 0.0040 & 2.68 \\
\hline Occupation & 0.0089 & 3.80 & 0.0021 & 2.22 & 0.0022 & 2.06 & 0.0022 & 2.17 & 0.0023 & 1.54 \\
\hline Industry & 0.0019 & 0.80 & -0.0002 & -0.20 & -0.0002 & -0.23 & -0.0002 & -0.21 & -0.0003 & -0.19 \\
\hline Province & 0.0412 & 17.49 & 0.0109 & 11.37 & 0.0116 & 10.98 & 0.0111 & 11.05 & 0.0126 & 8.50 \\
\hline Residual & 0.0724 & 30.75 & 0.0533 & 55.74 & 0.0633 & 59.91 & 0.0573 & 56.97 & 0.1053 & 70.81 \\
\hline Total & 0.2354 & 100 & 0.0957 & 100 & 0.1057 & 100 & 0.1006 & 100 & 0.1487 & 100 \\
\hline
\end{tabular}

Table 10. Decompositions of earnings inequality based on the Shorrocks approach for 1995

\begin{tabular}{|c|c|c|c|c|c|c|c|c|c|c|}
\hline & Gini & $\%$ & Atkinson & $\%$ & Theil & $\%$ & MLD & $\%$ & GE(2) & $\%$ \\
\hline Male & 0.0137 & 4.52 & 0.0036 & 2.17 & 0.0037 & 2.33 & 0.0038 & 2.06 & 0.0040 & 2.10 \\
\hline СРC & 0.0075 & 2.48 & 0.0023 & 1.39 & 0.0025 & 1.56 & 0.0025 & 1.34 & 0.0028 & 1.48 \\
\hline $\begin{array}{l}\text { Work } \\
\text { experience }\end{array}$ & 0.0421 & 13.94 & 0.0164 & 9.78 & 0.0152 & 9.49 & 0.0170 & 9.26 & 0.0147 & 7.80 \\
\hline Schooling & 0.0189 & 6.25 & 0.0051 & 3.03 & 0.0054 & 3.38 & 0.0053 & 2.88 & 0.0060 & 3.16 \\
\hline Ownership & 0.0273 & 9.04 & 0.0080 & 4.76 & 0.0080 & 5.00 & 0.0083 & 4.51 & 0.0083 & 4.37 \\
\hline Occupation & 0.0223 & 7.36 & 0.0069 & 4.09 & 0.0070 & 4.40 & 0.0072 & 3.90 & 0.0075 & 3.98 \\
\hline Industry & 0.0079 & 2.62 & 0.0019 & 1.11 & 0.0019 & 1.21 & 0.0019 & 1.05 & 0.0021 & 1.12 \\
\hline Province & 0.0784 & 25.92 & 0.0297 & 17.68 & 0.0334 & 20.86 & 0.0308 & 16.75 & 0.0388 & 20.50 \\
\hline Residual & 0.0843 & 27.87 & 0.0941 & 55.99 & 0.0829 & 51.76 & 0.1071 & 58.24 & 0.1049 & 55.48 \\
\hline Total & 0.3023 & 100 & 0.1681 & 100 & 0.1602 & 100 & 0.1840 & 100 & 0.1891 & 100 \\
\hline
\end{tabular}

Table 11. Decompositions of earnings inequality based on the Shorrocks approach for 2002

\begin{tabular}{|c|c|c|c|c|c|c|c|c|c|c|}
\hline & Gini & $\%$ & Atkinson & $\%$ & Theil & $\%$ & MLD & $\%$ & GE(2) & $\%$ \\
\hline Male & 0.0119 & 3.49 & 0.0035 & 1.82 & 0.0035 & 1.74 & 0.0037 & 1.71 & 0.0037 & 1.46 \\
\hline СРС & 0.0088 & 2.59 & 0.0031 & 1.60 & 0.0032 & 1.60 & 0.0032 & 1.52 & 0.0035 & 1.40 \\
\hline $\begin{array}{l}\text { Work } \\
\text { experience }\end{array}$ & 0.0196 & 5.73 & 0.0053 & 2.78 & 0.0053 & 2.62 & 0.0055 & 2.58 & 0.0055 & 2.16 \\
\hline Schooling & 0.0364 & 10.64 & 0.0128 & 6.64 & 0.0133 & 6.58 & 0.0133 & 6.26 & 0.0143 & 5.66 \\
\hline Ownership & 0.0315 & 9.20 & 0.0117 & 6.08 & 0.0115 & 5.71 & 0.0122 & 5.74 & 0.0118 & 4.66 \\
\hline Occupation & 0.0321 & 9.38 & 0.0120 & 6.24 & 0.0122 & 6.05 & 0.0126 & 5.89 & 0.0129 & 5.12 \\
\hline Industry & 0.0239 & 7.00 & 0.0082 & 4.25 & 0.0081 & 4.00 & 0.0086 & 4.01 & 0.0083 & 3.29 \\
\hline Province & 0.0705 & 20.62 & 0.0277 & 14.41 & 0.0309 & 15.29 & 0.0288 & 13.51 & 0.0354 & 14.00 \\
\hline Residual & 0.1071 & 31.34 & 0.1079 & 56.18 & 0.1138 & 56.39 & 0.1254 & 58.77 & 0.1575 & 62.24 \\
\hline Total & 0.3418 & 100 & 0.1921 & 100 & 0.2019 & 100 & 0.2133 & 100 & 0.2530 & 100 \\
\hline
\end{tabular}




\begin{tabular}{|c|c|c|c|c|c|c|}
\hline Earnings & 1988 & & 1995 & & 2002 & \\
\hline Male & 172.576 & *** & 283.016 & $* * *$ & 574.109 & *** \\
\hline СРС & 158.017 & $* * *$ & 204.248 & $* * *$ & 373.280 & $* * *$ \\
\hline Work experience & 56.136 & $* * *$ & 108.397 & $* * *$ & 110.242 & *** \\
\hline Work experience squared & -0.695 & $* * *$ & -1.844 & $* * *$ & -1.350 & $* * *$ \\
\hline Schooling & 45.161 & $* * *$ & 72.543 & $* * *$ & 222.327 & $* * *$ \\
\hline Central SOEs & 291.750 & $* * *$ & 808.006 & $* * *$ & 1172.673 & $* * *$ \\
\hline Local SOEs & 130.452 & $* * *$ & 352.637 & $* * *$ & 553.349 & $* * *$ \\
\hline Collective enterprises & - & & - & & - & \\
\hline $\begin{array}{l}\text { Private and individually owned } \\
\text { enterprises }\end{array}$ & 277.528 & $*$ & -95.281 & & 457.293 & $* * *$ \\
\hline Foreign enterprises & 759.819 & *** & 1031.010 & $* * *$ & 2162.845 & $* * *$ \\
\hline Other & -245.151 & $* *$ & 0.207 & & 879.634 & $* * *$ \\
\hline Professionals and technicians & 104.697 & $* * *$ & 364.310 & $* * *$ & 937.210 & *** \\
\hline Managers & 151.559 & $* * *$ & 420.095 & $* * *$ & 1314.598 & $* * *$ \\
\hline Clerks & 51.782 & $* * *$ & 117.870 & $* * *$ & 375.382 & $* * *$ \\
\hline Production workers & - & & - & & - & \\
\hline Other & 210.412 & & -34.352 & & -1005.874 & $* * *$ \\
\hline $\begin{array}{l}\text { Agriculture, forestry, husbandry, } \\
\text { fishing }\end{array}$ & -121.649 & $*$ & 101.419 & & 34.333 & \\
\hline Manufacturing & - & & - & & - & \\
\hline Mining and geological prospecting & 54.633 & & 29.308 & & 915.778 & $* * *$ \\
\hline Construction & -3.595 & & 190.509 & $* *$ & 442.275 & ** \\
\hline $\begin{array}{l}\text { Transportation, post and } \\
\text { telecommunications }\end{array}$ & 40.213 & & 278.462 & $* * *$ & 803.048 & $* * *$ \\
\hline $\begin{array}{l}\text { Commerce, trade, restaurants and } \\
\text { catering }\end{array}$ & 5.257 & & -61.650 & & -229.027 & $* *$ \\
\hline Real estate, public utilities & -141.683 & $* * *$ & 146.905 & $* *$ & -265.360 & $* *$ \\
\hline $\begin{array}{l}\text { Health, physical culture and social } \\
\text { welfare }\end{array}$ & -104.825 & $* * *$ & 204.081 & $* * *$ & 718.480 & $* * *$ \\
\hline Education, culture and arts & -95.100 & $* * *$ & 115.818 & $* *$ & 784.372 & $* * *$ \\
\hline $\begin{array}{l}\text { Scientific research and technical } \\
\text { services }\end{array}$ & -59.085 & & 123.552 & & 1406.311 & $* * *$ \\
\hline Finance, insurance & -164.575 & $* * *$ & 611.720 & $* * *$ & 822.809 & $* * *$ \\
\hline $\begin{array}{l}\text { Government and party organs, social } \\
\text { organizations }\end{array}$ & -172.553 & $* * *$ & 90.088 & * & 324.469 & $* * *$ \\
\hline Other & -320.889 & $* * *$ & 90.048 & & -33.175 & \\
\hline Beijing & - & & - & & - & \\
\hline Shanxi & -292.313 & $* * *$ & -1387.826 & $* * *$ & -3334.356 & $* * *$ \\
\hline Liaoning & -63.270 & * & -1070.081 & $* * *$ & -2417.203 & $* * *$ \\
\hline Jiangsu & -29.579 & & -405.152 & $* * *$ & -1920.400 & $* * *$ \\
\hline Anhui & -130.781 & $* * *$ & -1292.983 & $* * *$ & -2999.184 & $* * *$ \\
\hline Henan & -374.368 & $* * *$ & -1391.618 & $* * *$ & -3554.749 & $* * *$ \\
\hline Hubei & -160.829 & **** & -984.309 & $* * *$ & -3042.587 & *** \\
\hline Guangdong & 784.976 & *** & 1466.080 & $* * *$ & 546.562 & *** \\
\hline Sichuan & N.A. & & -975.711 & $* * *$ & -2159.894 & $* * *$ \\
\hline Chongqing & N.A. & & N.A. & & -2719.101 & $* * *$ \\
\hline Yunnan & 40.049 & & -1098.583 & $* * *$ & -2713.010 & $* * *$ \\
\hline Gansu & -111.142 & $* * *$ & -1548.299 & $* * *$ & -3273.027 & $* * *$ \\
\hline
\end{tabular}




\begin{tabular}{|c|c|c|c|c|c|c|}
\hline Constant & 295.267 & $* * *$ & 626.684 & $* * *$ & 854.399 & ** \\
\hline Adj. $R^{2}$ & 0.2674 & & 0.3741 & & 0.3221 & \\
\hline F-Value & 175.07 & & 181.14 & & 121.53 & \\
\hline Obs. & 16691 & & 10852 & & 9388 & \\
\hline
\end{tabular}

Note: ${ }^{* *},{ }^{* *}, *$ indicate statistical significance at the $1 \%, 5 \%$ and $10 \%$ levels, respectively. 


\section{Appendix. Brief introduction to the Shapley decomposition}

We use a simple case to explain the Shapley decomposition. Suppose that we have two factors, A and B, that affect income inequality. I(A, B) measures inequality caused by A and B together, while I(A) and I(B) denote the contributions of A and B to total income inequality, respectively. $\mathrm{I}(\Phi)$ represents income inequality when both $\mathrm{A}$ and $\mathrm{B}$ have no effect on inequality. In this case, $\mathrm{I}(\Phi)=0$.

\section{Appendix Figure. The Shapley decomposition}

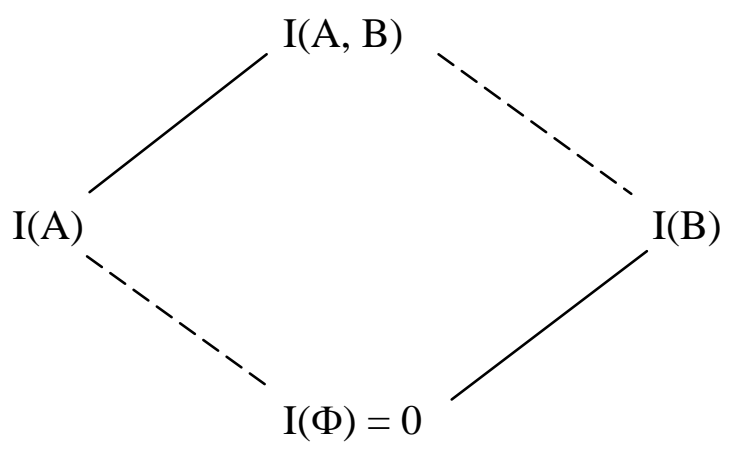

As suggested by the appendix figure, the marginal effect of A on income inequality can be obtained through two sequences; that is, $[\mathrm{I}(\mathrm{A}, \mathrm{B})-\mathrm{I}(\mathrm{B})]$ and $[\mathrm{I}(\mathrm{A})-\mathrm{I}(\Phi)]$. Taking the average, the contribution of A to total income inequality is $[\mathrm{I}(\mathrm{A}, \mathrm{B})-\mathrm{I}(\mathrm{B})+\mathrm{I}(\mathrm{A})-\mathrm{I}(\Phi)] / 2$. Likewise, the contribution of $\mathrm{B}$ to total income inequality is $[\mathrm{I}(\mathrm{A}, \mathrm{B})-\mathrm{I}(\mathrm{A})+\mathrm{I}(\mathrm{B})-\mathrm{I}(\Phi)] / 2$. If there are $\mathrm{m}$ factors, each factor will have $\mathrm{m}$ ! (factorial) marginal effects, the average of which yields the contribution of each factor to inequality.

Based on the Shapley decomposition, Wan (2004) investigates the residual and constant terms more closely. Wan (2004) proposes the following expressions for computing the contributions of the constant and residual terms to inequality.

$\mathrm{I}($ Residual $)=\mathrm{I}($ Constant, Residual, Causal effects $)-\mathrm{I}$ (Constant, Causal effects)

$\mathrm{I}($ Constant $)=\mathrm{I}($ Constant, Causal effects $)-\mathrm{I}$ (Causal effects) 